\title{
Communication
}

[Comunicação]

\section{Willingness of the consumers of the Federal District - Brazil - to purchase beef meat with certification of origin}

\author{
[Disposição dos consumidores do Distrito Federal em adquirir carne \\ bovina com certificação de origem] \\ L.L. Rigueira ${ }^{1}$, M.A. Lopes $^{2} *$, F.R.P. Bruhn ${ }^{2}$, C.G. Rodrigues ${ }^{3}$, P.B. Faria ${ }^{2}$ \\ ${ }^{1}$ Secretaria de Agricultura e Desenvolvimento Rural do DF (SEAGRI-DF) \\ ${ }^{2}$ Universidade Federal de Lavras - UFLA - Lavras, MG \\ ${ }^{3}$ Universidade Federal de Minas Gerais - CEDEPLAR-UFMG - Belo Horizonte, MG
}

Food safety performs a strategic role in world commerce and represents a global concern (Nesbaken, 2009). According to Sofos (2008), challenges related to the safety of products of animal origin and difficulties related to effective control of the processes generate the need to create mechanisms which reduce the potential risk of food-borne diseases. Traceability meets that perspective, since it integrates the whole productive chain into a monitoring and certification system. Becomes relevant, therefore, assess whether consumers know the concept of bovine traceability and if the meat which is currently marketed in large supermarket chains with certification of origin is included in the purchase desire, even if pay more dearly for this product. So, the objective of this work was to identify the main attributes of beef which influence the decision to purchase it, surveying the willingness of these consumers to pay more for meat with certification of origin and identifying the main benefits and difficulties in the sale of meat with certification of origin, from the standpoint of the supermarket managers.

The present work was conducted in nine supermarkets in the Federal District, Brazil. A total of 197 consumers of beef and the managers of the nine supermarkets visited were interviewed from May $13^{\text {rd }}$ to $17^{\text {th }}, 2011$. To determine the total number of interviewees, an intentional sampling technique was used, considering a maximum sampling error of $8 \%$,

Recebido em 18 de junho de 2013

Aceito em 31 de julho de 2014

*Autor para correspondência (corresponding author)

E-mail: malopes@dmv.ufla.br according to the Barbetta's methodology (2002) for an estimated population of 2,469,489 inhabitants in the Federal District (IBGE, 2011).

For information collection, interviews were applied from semi-structured questionnaires adapted from Velho (2009). The interviewees were randomly selected while they stood in front of the gondola of meats in the supermarket. First, the interviewees were classified into groups related to income (Brazilian minimum wage at the time of the interview was $\mathrm{R} \$ 545.00)$, and age range, how many years of study they had completed and whether they were men or women. All the interviewees reported the attributes which would make them decide to purchase meat and their consumption habits, knowledge and perception about products of animal origin with certification. Only the consumers which had already heard of bovine traceability were questioned. In the case of the interviewees who reported never having heard of bovine traceability, their questionnaires were restricted to stratification of socio-demographic variables and selection of the attributes important to their purchase.

The managers were interviewed in relation to the commercial potential of bovine traceability in Brazil. They were questioned in relation to the advantages of commercialization of the tracked meat and its possible gains, as well as whether there were difficulties for the sale of the product and, if so, what they might be. 
To evaluate of the information, descriptive analysis of the data obtained from the interviews with managers and consumers was conducted, and evaluation of the association between the socio-demographic variables surveyed in this study was performed by means of the Chi-square test $\left(x^{2}\right)$. The $x^{2}$ test is a statistical tool which allows evaluation of the occurrence of associations between two qualitative variables, this relationship being quantified by the value of Odds Ratio (OR). In the present work, OR and its confidence interval - CI (95\%) - were utilized in the interpretation of the results to express the chance of greater or smaller occurrence of a variable in relation to the other. All the statistical analyses were performed with the statistical package SPSS $17.0^{\circledR}$.

Of the 197 consumers interviewed, 56\% were female. As to age of the interviewees $37 \%$ were in the age range from 20-30 year-old; $31 \%$ were from 31 to 40 year-old; $13 \%$ were from 41 to 50 year-old; $13 \%$ were from 51 to 60 and $6 \%$ were over 61 year-old. In relation to the family income, 20\% received up to three times minimum wage; $18 \%$ from four to six times; $21 \%$ from seven to 10 times and $41 \%$ more than 11 times minimum wage. As for the educational level, 16\% successfully finished elementary school; 36\% finished senior high school; 37\% finished college and $10 \%$ possessed graduate education.

In relation to the factors which influenced the decision-taking of the consumers for the choice of meat, the work revealed that visual appearance was the preference of the customers $-26 \%$ of the choices. The other attributes were: price, shelflife, smallest amount of fat, SIF certification (Federal Inspection System) and place of purchase which accounted for $67 \%$ of the purchase options.

Visual appearance is concerned with general visual aspects and include the colour and apparent texture of the meat, Consonant with that result, Ubilava and Foster (2009) suggested by means of a logistic regression model that in the Republic of Georgia, both the consumers and the integrant of the productive chain of meat would be concerned firstly with the visual appearance of meat. Similar results were also found by Velho et al. (2009), who reported that $57.6 \%$ of interviewees in Rio Grande do Sul, 64\% of whom were female and 52\% male, chose meat on the basis of its colour.

The interviewees from 21 to 30 year-old were most likely to choose meat for its visual appearance $(\mathrm{P}<0.05)$. That is, there is more than three times the likelihood that individuals aged from 21 to 30 will choose meat for its visual appearance when compared with other age ranges $(\mathrm{OR}=3.3$; CI $(95 \%)=1.4-10.0)$. That fact can be described to increased worries in that group in relation to quality, innocuity of the products, animal welfare before slaughter, use of substances such as hormones and antibiotics, and occurrences of Bovine Spongiform Encephalopathy (BSE) and food contamination with residues such as dioxins which, according to Lopes et al. (2007), are events which have affected the beef chain in recent decades.

A statistical association was identified $(\mathrm{P}<0.05)$ between the price (as an important attribute for choosing) and the preference for beef with certification of origin (rather than the traditional), because consumers believe that this kind of products bring the advantage of better quality $(\mathrm{OR}=3.0$, CI $(95 \%)=1.4$ to 6.4$)$. The results found by Morkbak et al. (2008) pointed out that consumers tend to be willing to purchase the product when, among other attributes, food safety aspects are present. Grunert et al. (2004) stressed that it is necessary to assure a warrant of origin for a product, showing that good manufacturing practices were used and that it is fit receive a certificate of origin analogically with the certificate of warrant of any other product, adding a level of confidence to the buyer's purchase. To improve the perception of food safety, Angulo and Gil (2007) stressed that quality control systems should be strengthened and divulged to the population, so that they have a greater awareness of them.

The location in which the meat is bought, stated as a choice criterion by $7.9 \%$ of interviewees, may be related to adherence to the desire to buy meat with certification of quality. The customers who ascribed their choice of meat to a point of sale tended to prefer $(\mathrm{P}<0.05)$ to consume products with a stamp of certification of quality on the package $(\mathrm{OR}=3.8$; IC $(95 \%)=1.3-11.3)$ and believed $(\mathrm{P}<0.05)$ that meat with certification of origin presents increased 
competitiveness on abroad market $(\mathrm{OR}=5.4$; IC $(95 \%)=1.3-21.6)$.

Of the 197 interviewees, 115 (58.4\%) answered that they had already heard of bovine traceability. Of those, only 39\% could report the correct concept regarding meat with certification of origin. The consumers who reported the correct concept of meat with certification of origin - products which offer information on origin - believe that such certification contributes $(\mathrm{P}<0.05)$ towards increased food safety $(\mathrm{OR}=2.6$; IC $(95 \%)=1.1-6.4)$. However, even consumers who were not able to describe the correct concept of meat with certification of origin, they still believe that certification aggregates $(\mathrm{P}<0.05)$ benefits to the consumer $(\mathrm{OR}=9.7$; IC $(95 \%)=2.1-44.8)$.

Although more than half of interviewees (52\%) in associating that meat with certification of origin is simply that checked by the official inspection service (diverging of the correct concept of traced meat), these consumers tended to present $(\mathrm{P}<0.05)$ greater preference for consumption of products of animal origin with certification $(\mathrm{OR}=4.5$; IC $(95 \%)=1.7-12.0)$.

Of the 115 consumers who had already heard of bovine traceability, 90 (78.3\%) stated that they would be willing to pay more for meat with certification of origin. In this work, it was found that the willingness of those 90 consumers to purchase meat with certification of origin increased according to their educational level, corroborating the results of Solomon et al. (2006). As those concluded higher education, $92 \%$ would be willing to pay more for meat with certification of origin, compared $41 \%$ of those Elementary School only.

The correct concept of meat with certification of origin was provided by $75 \%$ of consumers who had completed a graduate course $(\mathrm{P}<0.05$; $\mathrm{OR}=11.2$; CI $(95 \%)=1.7-72.3)$ and $80 \%$ of those who had completed undergraduate study $(\mathrm{P}<0.05 ; \quad \mathrm{OR}=4.8 ; \quad$ CI $\quad(95 \%)=1.5-15.4)$. In addition, college-educated interviewees considered that meat with certification of origin transmitted confidence to the consumer that there was a reduced $(\mathrm{P}<0.05)$ risk of food-borne diseases $(\mathrm{OR}=3.1$; CI $(95 \%)=1.1-9.0)$.
In this work, family income proved not to be a factor of influence in the decision to pay more for beef $(\mathrm{P}>0.05)$ - interviewees with a higher range of family income did not show greater willingness to pay more for certified products. The results suggest that income as an isolated factor is not a pre-requisite for purchase. However, one must consider that $41 \%$ of the interviewees possessed a family income of more than 11 times the minimum wage. It is therefore suggested that consumers belonging to more fortunate social classes shop in the supermarkets which comercialize meat products with certification of origin.

In relation to the demographic variables, it was found that both gender and age range exercised an influence upon willingness to buy meat with certification of origin. The results pointed out that $81 \%$ of females and $75 \%$ of males would buy a product with certification of origin even there was an increase in the final price

Those results corroborate those obtained by Solomon et al. (2006), who stated that the search for food products with certification of origin is a tendency among young females.

In spite of the fact that $78 \%$ of interviewees who understood bovine traceability stating that they would pay more for meat with certification of origin, the increase agreed on by the consumers in this survey was low. Consumers aged from 31 to 40 year-old had higher adherence to the purchase of meat products with certification of origin increase of just $5 \%$ of the product price was regarded as acceptable by $53 \%$ of consumers A total of nine units from different supermarket chains were visited and in each shop a manager was interviewed; therefore, nine interviews were undertaken. Of the managers, $47 \%$ described the loyalty of more demanding costumers as the main advantage gained through selling meat with certification of origin

A total of $23 \%$ of the managers stated the traceability allows a better customer service once it is easily possible to do product's recalls and figure consumer's claims out. Traceability makes it possible to note where the product came from and the moment at which the problem may have occurred. In the case of beef with certification of origin, it is possible to gain information about the farm and meat-packing plant which slaughtered 
the lot, offering the ability to localize the failure and adopt corrective actions in the slaughterhouse or farm of origin, contributing in that way to improvement in food safety.

In the opinion of the managers, the current demand for meat with certification of origin remains small, as consumers are not willing to pay a higher price for unknown advantages. It was observed in this research that the lack of disclosure of the bovine traceability for the population was reported as the main difficulty for the marketing of products with certification of origin.

At the points of sale visited, no posters were seen offering information about tracked products. Still, it was noted that certified meat occupies a small space in the gondola, and can pass almost unnoticed by consumers. The provision of information insufficient to the consumer suggests that the managers possess little initiative in relation to bovine traceability marketing; they could be more active and promote products with certification of origin to their customers. Finally, in the perception of the managers, the bovine traceability is being considered a trend in Brazil.
From this work, it is concluded that most part of respondents recognize the term traced meat, but does not know its concept, and individuals with higher schooling are more likely to know the correct concept. These data are important because we also found that the knowledge of the correct concept of traced meat, as well as education levels, is associated with the perception that this type of product presents greater food security. The majority of respondents reported that they would accept paying more for traced meat, but up to $5 \%$ increase. Nevertheless, in the opinion of the managers of the supermarkets, the main factor that affects the trade is the low knowledge of the population about the advantages of traced meat, which generates a low acceptability to pay more. Thus, awareness campaigns and information to population are important ways to increase demand for the traced meat, because this study demonstrated that knowledge about traceability is connected to a more favorable perception about certified meat.

Keywords: meat attributes, origin certification, traceability

\section{RESUMO}

Este trabalho objetivou identificar os atributos que influenciam a tomada de decisão para a compra de carne bovina, além do conhecimento e atitude dos consumidores em adquirir carne com certificação de origem, assim como os principais benefícios e dificuldades para a comercialização desse produto. Foram entrevistados 197 consumidores e nove gerentes de supermercados no Distrito Federal, em maio de 2011. Foi realizada a descrição das variáveis e aplicados o teste do qui-quadrado e o Exacto de Fischer, utilizando o pacote estatístico SPSS 17.0. A aparência visual da carne é o atributo que mais influencia a decisão de compra dos consumidores. A maioria dos entrevistados está disposta a pagar mais pela carne com certificação de origem. Esta pesquisa sugere que a escolaridade é o fator que mais influencia a disposição para compra de carne com certificação de origem. Os gerentes de supermercados salientam a fidelização de clientes mais exigentes como o maior benefício, e a falta de divulgação da rastreabilidade bovina para a população como a principal dificuldade para a comercialização.

Palavras-chave: atributos da carne, certificação de origem, rastreabilidade

\section{ACKNOWLEDGEMENTS}

To FAPEMIG (Fundação de Amparo à Pesquisa do Estado de Minas Gerais) and CNPq (Conselho Nacional de Desenvolvimento Científico e Tecnológico), for the support to this study.

\section{REFERENCES}

ANGULO, A.M.; GIL, A.J.M. Risk perception and consumer willingness to pay for certified beef in Spain. Food Qual. Prefer, v.18, p.1106-1117, 2007.

BARBETTA, P.A. Estatística aplicada às Ciências Sociais. 7.ed. Florianópolis, Editora UFSC, v.1, 2007. 315p. 


\section{Rigueira et al.}

GRUNERT, K.G.; BRUNSO, K.; BREDAHL, L. Consumer perception of meat quality and implications for product development in the meat sector - a review. Meat Sci., v.66, p.259-272, 2004.

IBGE. Instituto Brasileiro de Geografia e Estatística 2011. Disponível em: <http://www.ibge.gov.br/home/ estatistica/populacao/censo2010/resultados_dou/DF20 10.pdf>. Acessado em: 01 mai. 2011.

LOPES, M.A.; SANTOS, G.; AMADO, G.B. et al. Principais dificuldades encontradas pelos pecuaristas na implantação da rastreabilidade de bovinos. Cienc. Anim. Bras., v.8, p.515-520, 2007.

MORKBAK, M.R.; CHRISTENSEN, T.; GYRDHANSEN, D. Valuation of food safety in meat - a review of stated preference studies. Food Econ., v.5, p.63-74, 2008.
NESBAKEN, T. Food Safety in a global market - Do we need to worry? Small Ruminant Res., v.86, p.6366, 2009.

SOFOS, J.N. Challenges to meat safety in the 21st century. Meat Sci., v.78, p.3-13, 2008.

SOLOMON, M.; BAMOSSY, G.; ASKEGAARD, S. et al. Consumer behaviour. A European perspective. Harlow: Prentice Hall, v.3 p.265, 2006.

UBILAVA, D.; FOSTER, K. Quality certification vs. product traceability: Consumer preferences for informational attributes of pork in Georgia. Food Policy, v.34, p.305-310, 2009.

VELHO, J.P.; BARCELLOS, J.O.J.; LENGLER, L. et al. Disposição dos consumidores porto-alegrenses à compra de carne bovina com certificação. Rev. Bras. Zootec., v.38, p.399-404, 2009. 